\title{
Crude glycerin changes ruminal parameters, in vitro greenhouse gas profile, and bacterial fractions of beef cattle
}

\author{
E.H.C.B. van Cleef $^{\text {a,* }}{ }^{\text {, M.T.C. Almeida }}{ }^{a}$, H.L. Perez ${ }^{\text {a }}$, F.O.S. van Cleef $^{\text {a }}$, D.A.V. Silva ${ }^{a}$, \\ J.M.B. Ezequiel ${ }^{\mathrm{a}}$ \\ a College of Agrarian and Veterinarian Sciences, São Paulo State University "Júlio de Mesquita Filho", 14884-900 Jaboticabal, São Paulo, Brasil
}

\section{A R T I C L E I N F O}

\section{Article history:}

Received 16 October 2014

Received in revised form

12 May 2015

Accepted 22 June 2015

Keywords:

Glycerin

Greenhouse gas

Rumen microorganism

$\mathrm{pH}$

\begin{abstract}
A B S T R A T
As the biodiesel industry produces a large surplus of crude glycerin, this by-product is increasingly being considered as an attractive source of energy to replace corn in livestock diets. The objective of this study was to evaluate how the inclusion of up to $30 \%$ crude glycerin in Nellore cattle diets affects ruminal parameters such as $\mathrm{pH}$, ammonia, and volatile fatty acids as well as greenhouse gas production, and concentration of the protozoal and bacterial fractions. Five ruminally cannulated Nellore steers were randomly assigned in a $5 \times 5$ Latin square design and fed diets containing 30\% corn silage and 70\% concentrate composed of sunflower meal, corn grain, soybean hulls, minerals, and $0,7.5,15,22.5$, or 30\% crude glycerin $(860 \mathrm{~g}$ glycerol $/ \mathrm{kg}$ ). After $14 \mathrm{~d}$ of adaptation, animals were submitted to rumen content sampling for $7 \mathrm{~d}$. With the supplementation of glycerin in the diets, total VFA and acetate concentrations decreased (linear, $P=0.03, P<0.0001$, respectively), and propionate concentrations increased (linear, $P=0.007$; quadratic, $P=0.008$ ), leading to an acetate to propionate ratio decrease (linear, $P<0.0001$ ). The rumen ammonia was not affected while $\mathrm{pH}$ was quadratically affected and was lesser for glycerin treatments (quadratic, $P=0.04$ ). Methane production was reduced (linear, $P<0.0001$ ) when glycerin was added, as well as the $\mathrm{CO}_{2}$ (linear, $P<0.0001$; quadratic, $P=0.0001$; cubic, $P<0.0001$ ). The concentration of liquid phase microorganisms was not affected, while the concentration of particle-associated bacteria fraction was decreased by the addition of crude glycerin in the diets. The inclusion of up to $30 \%$ of crude glycerin in diets for beef cattle decreased ruminal concentration of total VFA and acetate, increased propionate, reduced concentration of particle-associated bacteria, and decreased production of methane.
\end{abstract}

(c) 2015 Elsevier B.V. All rights reserved.

\section{Introduction}

The increase in biodiesel production worldwide has been welcomed as a much needed alternative energy source for the challenges facing the world. However, it also results in price increases of several agricultural commodities that are used for biofuel production, including corn (Anderson et al., 2008). Besides being a staple human food, corn is an important feed grain for livestock, but its market price is driving farmers to search for alternative feed sources. As the biodiesel industry produces a large surplus of crude glycerin, this by-product is increasingly being considered an attractive source of energy to replace corn. The economic and humanitarian gains of such strategy may be auspicious as it could increase the availability of this crop for the needs of human nutrition.

\footnotetext{
* Correspondence to: Via de Acesso Paulo Donato Castellane, s/n, Bairro Rural, Jaboticabal 14884-900, São Paulo, Brasil.

E-mail address: ericvancleef@gmail.com (E.H.C.B. van Cleef).
}

Promising results regarding productivity and feed efficiency have been reported for the inclusion of up to $20 \%$ crude glycerin in diets for ruminants (Gunn et al., 2010). Because the amount of glycerin fed to the animals may affect fermentation and absorption in the rumen, studies examining greater inclusions of crude glycerin in the diet are warranted. Indeed, previous studies have shown a negative impact of glycerin on the growth of cellulolytic bacteria (Roger et al., 1992), resulting in reductions in digestibility of fiber (Donkin et al., 2009; Shin et al., 2012; Van Cleef et al., 2014), and probably decreasing the production of methane (Holter and Young, 1992). Thus, it becomes imperative to investigate whether replacing corn with a greater percentage of glycerin in cattle diets can maintain adequate ruminal conditions reducing enteric methane emissions. This is an important question because while the global demand for food availability stimulates livestock production, it also leads to increasing emissions of greenhouse gases.

The objective of this study was to evaluate how the inclusion of up to $30 \%$ crude glycerin in Nellore cattle diets affects in vivo 
ruminal parameters such as $\mathrm{pH}$, ammonia, volatile fatty acids, and microbial concentrations as well as in vitro greenhouse gas production.

\section{Materials and methods}

The trials were conducted at Animal Science Department of São Paulo State University (UNESP), Jaboticabal Campus. The cannulation procedures and the use of the ruminally cannulated animals in these experiments were approved by the Animal Welfare and Ethics Commission from São Paulo State University (Protocol 010707).

\subsection{Animals and experimental design}

Five ruminally cannulated Nellore steers averaging 24 months of age and $400 \mathrm{~kg}$ BW were assigned to a $5 \times 5$ Latin square arrangement of treatments. The animals were housed in individual semi-roofed, concrete-surfaced pens $\left(12 \mathrm{~m}^{2}\right)$, with feed bunks and waterers, and received the experimental diets for 21-d periods, composed of $14 \mathrm{~d}$ of adaptation and $7 \mathrm{~d}$ of data collection.

The diets contained similar protein (122 g CP/ $\mathrm{kg} \mathrm{DM})$ and energy (2.5 Mcal EM/kg DM) concentrations and were formulated to supply the requirements of Nellore steers in feedlot according to NRC-National Research Council (1996), and fed to the animals in a roughage:concentrate ratio of 30:70 (Table 1). The following treatments were evaluated: G0 - (control), no crude glycerin (CGL) inclusion in the diet; G7.5-75 g CGL/kg of dietary dry matter (DM); G15-150 g CGL/kg dietary DM; G22-220 g CGL/kg dietary DM; and G30-300 g CGL/kg dietary DM. The CGL inclusion concentrations are described on a DM basis.

The CGL tested contained $860 \mathrm{~g}$ glycerol/kg of DM, $950 \mathrm{~g}$ of DM/ $\mathrm{kg}, 1.1 \mathrm{~g} \mathrm{CP} / \mathrm{kg}$ of DM, $60 \mathrm{~g}$ salts $/ \mathrm{kg}$ of DM, and less than $0.01 \%$ methanol. The roughage used was corn silage and the concentrate was composed of ground corn grain, soybean hulls, sunflower meal, salt, limestone, and dicalcium phosphate. The animals were fed twice daily at 0800 and $1800 \mathrm{~h}$, about $8 \mathrm{~kg}$ (DM basis), and fresh water was available throughout the experiment. The feed delivery was controlled by observing bunk scores between 0 and 1

Table 1

Percentage of feed ingredients and nutrient composition of experimental diets.

\begin{tabular}{|c|c|c|c|c|c|}
\hline \multirow[t]{2}{*}{ Item } & \multicolumn{5}{|c|}{ Treatments $^{\mathrm{a}}$} \\
\hline & G0 & G7.5 & G15 & G22.5 & G30 \\
\hline \multicolumn{6}{|l|}{ Ingredients ( $\mathrm{g} / \mathrm{kg} \mathrm{DM})$} \\
\hline Corn silage & 300.0 & 300.0 & 300.0 & 300.0 & 300.0 \\
\hline Corn grain & 350.0 & 255.0 & 180.0 & 125.0 & 50.0 \\
\hline Soybean hulls & 192.0 & 180.5 & 145.5 & 89.0 & 54.5 \\
\hline Sunflower meal & 146.0 & 178.0 & 213.0 & 249.0 & 284.0 \\
\hline Crude glycerin & - & 75.0 & 150.0 & 225.0 & 300.0 \\
\hline Salt $(\mathrm{NaCl})$ & 5.0 & 5.0 & 5.0 & 5.0 & 5.0 \\
\hline Limestone & 7.0 & 6.5 & 5.5 & 7.0 & 6.5 \\
\hline Dicalcium phosphate & - & 1.0 & 1.0 & - & - \\
\hline \multicolumn{6}{|c|}{ Calculated chemical composition } \\
\hline $\mathrm{CP}(\mathrm{g} / \mathrm{kg} \mathrm{DM})$ & 122.0 & 122.1 & 122.2 & 122.0 & 122.1 \\
\hline ME (Mcal/kg DM) & 2.5 & 2.5 & 2.5 & 2.5 & 2.5 \\
\hline $\mathrm{EE}(\mathrm{g} / \mathrm{kg} \mathrm{DM})$ & 29.0 & 25.8 & 23.1 & 20.9 & 18.1 \\
\hline $\mathrm{NDF}(\mathrm{g} / \mathrm{kg} \mathrm{DM})$ & 408.3 & 400.7 & 381.1 & 350.1 & 330.8 \\
\hline $\mathrm{ADF}(\mathrm{g} / \mathrm{kg} \mathrm{DM})$ & 254.1 & 255.6 & 247.1 & 228.9 & 220.6 \\
\hline HEM (g/kg DM) & 154.2 & 145.1 & 134.1 & 121.2 & 110.2 \\
\hline $\mathrm{Ca}(\mathrm{g} / \mathrm{kg} \mathrm{DM})$ & 5.6 & 5.6 & 5.5 & 5.7 & 5.5 \\
\hline $\mathrm{P}(\mathrm{g} / \mathrm{kg} \mathrm{DM})$ & 3.2 & 3.2 & 3.5 & 3.4 & 3.4 \\
\hline
\end{tabular}

a $\mathrm{G} 0=$ Without crude glycerin; G7.5=75 g crude glycerin $/ \mathrm{kg} \mathrm{DM} ; \mathrm{G} 15=150 \mathrm{~g}$ crude glycerin $/ \mathrm{kg}$ DM; G22.5 $=225 \mathrm{~g}$ crude glycerin $/ \mathrm{kg} \mathrm{DM} ; \mathrm{G} 30=300 \mathrm{~g}$ crude glycerin/kg DM
(Pritchard, 1993).

\subsection{Rumen $\mathrm{pH}$, ammonia, and VFA profiles}

This trial was conducted at Laboratory of Ingredients and Pollutant Gases of the Animal Unit of Digestive and Metabolic Studies from São Paulo State University-Jaboticabal Campus.

Rumen fluid samples were collected on d 15 of each experimental period, at $-1,0,2,4,6$, and $8 \mathrm{~h}$ after feeding. Approximately $500 \mathrm{~g}$ of ruminal content of each animal adapted to each experimental diet were collected from the dorsal and ventral rumen, and strained through four layers of cheesecloth to separate liquid and solid phases. Five milliliters of the filtrate was preserved by storing at $-20^{\circ} \mathrm{C}$ in a freezer for later analysis of VFA profiles. The $\mathrm{pH}(n=1)$ was determined immediately after rumen fluid sampling by using a digital $\mathrm{pH}$ meter, and ammonia concentrations $(n=2)$ was determined using a micro-Kjeldhal device, using $5 \mathrm{~mL}$ of $\mathrm{KOH} 2 \mathrm{~N}$, and a distillation flux of $2 \mathrm{~mL} / \mathrm{min}$. The distilled sample was dropped in $10 \mathrm{~mL}$ boric acid solution (2\%), and then titrated with $\mathrm{HCl} 0.005 \mathrm{~N}$.

In due course, the rumen fluid samples reserved previously were thawed and VFA profiles were evaluated $(n=2)$. For sample preparation, $1.6 \mathrm{~mL}$ of rumen fluid was centrifuged $(15,000 \mathrm{~g}$; $15 \mathrm{~min}$; $4{ }^{\circ} \mathrm{C}$; Sorvall Superspeed RC2-B, Newton, CT, USA) with $0.4 \mathrm{~mL}$ of 3:1 metaphosphoric acid 25\% (Vetec Química Fina Ltd) and formic acid $98-100 \%$ (Merck KGaA), and $0.2 \mathrm{~mL}$ of 2-ethilbutyric acid $100 \mathrm{mM}$ (internal standard; $\mathrm{PM}=116.16$; CAS 88-09-5; Sigma Chemie Gmbh). After centrifugation, approximately $1.2 \mathrm{~mL}$ of supernatant was transferred to chromatographic vials. The concentration of VFA was determined by injecting $1 \mu \mathrm{L}$ of sample in a gas chromatograph (CG HP 7890 A; Injector HP 7683B, Agilent Technologies, Palo Alto, CA, USA) equipped with a HP-FFAP capillary column (19091 F-112; 25 m; 0.320 mm; $0.50 \mu \mathrm{m}$; J\&W Agilent Technologies Inc.; Palo Alto, CA, USA). The calibration curve was made using chromatographic standards (Chem Service, West Chester, PA, USA) of acetic acid (99.5\%; CAS 64-19-97), propionic acid (99\%; CAS 79-09-4), isobutyric acid (99\%; CAS 79-31-2), butyric acid (98.7\%; CAS 107-92-6), isovaleric acid (99\%; CAS 503-742 ), and valeric acid (99\%; CAS 109-52-4)

\subsection{Gas measurements}

The incubation took place between d 16 and d 18 of each experimental period. The methodology adopted in this trial for determination of in vitro gas production was adapted from Pereira et al. (2006), and consists of three main steps:

Sample preparation: Approximately $4 \mathrm{~kg}$ of ruminal content of each adapted animal to each diet were manually collected, and strained through a nylon filter $(100 \mu \mathrm{m}) ; 125 \mathrm{~mL}$ of the filtrate was then transferred to $250 \mathrm{~mL}$ plastic Erlenmeyers containing $1.7 \mathrm{~g}$ of each diet used $(n=3)$, in order to maintain a 1:8 ratio of sample and ruminal liquid. Two Erlenmeyers with only rumen fluid were used as blanks for each treatment in each period.

Gas production and storage: The Erlenmeyers were purged with anaerobic gas, capped with stoppers, and attached to a gasometer made of PCV pipe, and 500-mL PET bottles. The device was incubated in a water-bath at $39^{\circ} \mathrm{C}$ for a 12 -h period.

Gas sampling and qualitative analysis: The total gas production was measured using a graduated ruler and correlated with a standard curve previously made to convert height to volume, according to the bottle area. The gas was sampled with a $1-\mathrm{mL}$ syringe and $0.5 \mathrm{~mL}$ was immediately injected into a gas chromatograph (Trace GC Ultra ${ }^{\mathrm{TM}}$, Thermo Scientific). The GC was equipped with a Porapak column and molecular sieve. The oven temperature was set to $70{ }^{\circ} \mathrm{C}$, and the injector temperature used was $110{ }^{\circ} \mathrm{C}$. The carrier gas used was argon, with $25 \mathrm{~mL} / \mathrm{min}$ flow. 


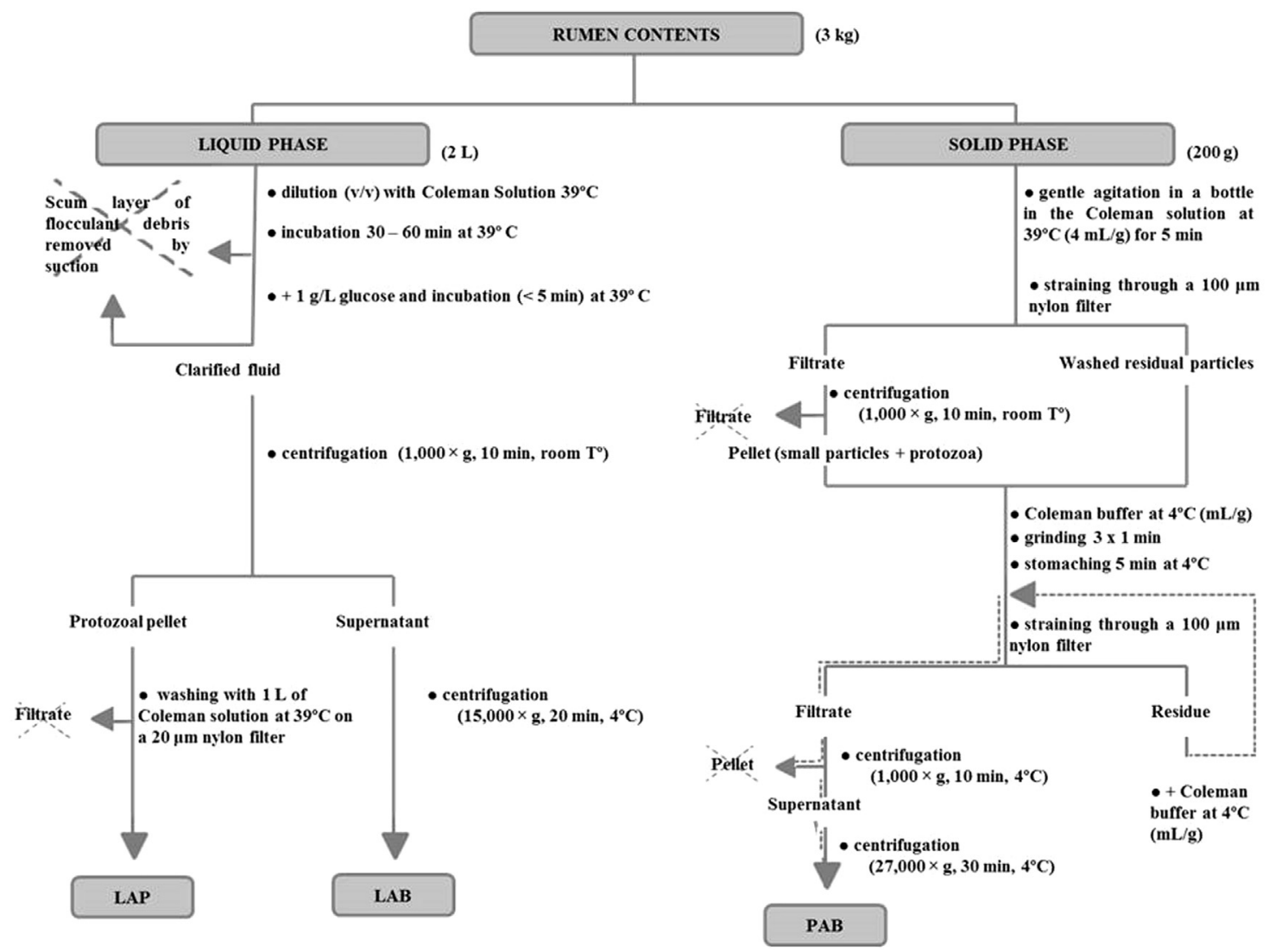

Fig. 1. Procedure to isolate liquid-associated protozoa (LAP) and bacteria (LAB) and particle-associated bacteria (PAB).

\subsection{Protozoal and bacterial fractions}

This trial used methodology adapted from Martin et al. (1994), illustrated in Fig. 1. Approximately $3 \mathrm{~kg}$ of ruminal content was sampled from the dorsal and ventral rumen from each adapted animal in each period, 2,4 , and $12 \mathrm{~h}$ after morning feeding. To avoid any interference in ruminal function only one sample of ruminal content was taken per day, between d 19 and d 21 of each experimental period.

The ruminal content was strained through a nylon filter $(100 \mu \mathrm{m})$ in order to separate liquid and solid phases. Two hundred grams of the solid content was weighed, of which $30 \mathrm{~g}$ was used for DM analyses, and $170 \mathrm{~g}$ was used for isolation of particleassociated bacteria (PAB). The solid material was initially washed by manual shaking with a pre-warmed $\left(39^{\circ} \mathrm{C}\right)$ Coleman saline solution $\left(0.63 \% \mathrm{~K}_{2} \mathrm{HPO}_{4}, 0.5 \% \mathrm{KH}_{2} \mathrm{PO}_{4}, 0.065 \% \mathrm{NaCl} \cdot 6 \mathrm{H}_{2} \mathrm{O}, 0.09 \%\right.$ $\mathrm{MgSO}_{4} \cdot 7 \mathrm{H}_{2} \mathrm{O}, 0.5 \%$ cysteine hydrochloride), using a ratio of $1 \mathrm{~g}$ of solid to $4 \mathrm{~g}$ of saline solution. The content was filtered through a nylon filter $(100 \mu \mathrm{m})$. The filtrate was then centrifuged at room temperature (1000g, for $10 \mathrm{~min}$ ). The pellet of small particles obtained was added to the content retained on the filter. This combined material was suspended in pre-cooled Coleman solution $\left(4^{\circ} \mathrm{C}\right)$, and homogenized at $200 \mathrm{rpm}$ for $5 \mathrm{~min}$ using a Stomacher device (Seward and Co., London). The material was filtered again and the solid retained was discarded. The filtrate was centrifuged (1000g, for $10 \mathrm{~min}$, at $4{ }^{\circ} \mathrm{C}$ ) and the supernatant was centrifuged again $\left(27,000 \mathrm{~g}\right.$, for $30 \mathrm{~min}$, at $\left.4^{\circ} \mathrm{C}\right)$. The resulting pellet was considered as the PAB. The bacterial material was transferred to $100-$ $\mathrm{mL}$ plastic flasks and dried at $55^{\circ} \mathrm{C}$ for $72 \mathrm{~h}$. Subsequently, the flasks with dried $\mathrm{PAB}$ were weighed and reserved for further analyses of DM, mineral matter, and N (AOAC, 1990).

From the liquid phase, separated at the beginning from the $3 \mathrm{~kg}$ of ruminal content, $700 \mathrm{~mL}$ was diluted with pre-warmed $\left(39^{\circ} \mathrm{C}\right)$
Coleman saline solution (1:1) and incubated in water bath at $39{ }^{\circ} \mathrm{C}$ for $30 \mathrm{~min}$, until the flocculation was complete. After $25 \mathrm{~min}$ of incubation, $1 \mathrm{~g} / \mathrm{L}$ glucose was added in order to separate the protozoa from the rest of the ruminal liquid. After that, $400 \mathrm{~mL}$ of clarified fluid was centrifuged $(1000 \mathrm{~g}$, for $10 \mathrm{~min}$, at room temperature) and the pellet of liquid-associated protozoa (LAP) was recovered. The pellet was washed with a pre-warmed Coleman saline solution $\left(39^{\circ} \mathrm{C}\right)$, and filtered through a $20-\mu \mathrm{m}$ nylon filter.

The liquid-associated bacteria (LAB) was recovered by centrifuging the protozoa-free supernatant $(15,000 \mathrm{~g}$, for $20 \mathrm{~min}$, at $4{ }^{\circ} \mathrm{C}$ ). The pellets of LAP and LAB were transferred to $100-\mathrm{mL}$ plastic flasks and dried at $55^{\circ} \mathrm{C}$ for $72 \mathrm{~h}$. Subsequently, the flasks with dried microorganisms were weighed and reserved for further analyses of DM, mineral matter, and N (AOAC, 1990).

\subsection{Statistical analysis}

The variables $\mathrm{NH}_{3}-\mathrm{N}, \mathrm{pH}, \mathrm{VFA}$, and microbial fractions (LAB, $\mathrm{PAB}$, and LAP) were analyzed as a $5 \times 5$ Latin square with repeated measures, using the MIXED procedure of SAS, version 9.1. The model included fixed effects of treatment, time, and their interaction, as well as random effects of animal and period. Several covariance structures were tested and the best one was chosen for each variables, based on Akaike information criterion. The degrees of freedom and tests were adjusted using the option KR. The linear, quadratic and cubic effects of crude glycerin were tested, as well as the contrast control treatment $\times$ crude glycerin treatments. Data from the gas production study were analyzed as a $5 \times 5$ Latin square and the same effects were evaluated. The significance was declared as $P<0.05$, and tendency was declared as $P \leq 0.10$. 
Table 2

Effects of crude glycerin on ruminal volatile fatty acids, $\mathrm{pH}$, and ammonia nitrogen in Nellore steers.

\begin{tabular}{|c|c|c|c|c|c|c|c|c|c|c|}
\hline \multirow[t]{2}{*}{ Item } & \multicolumn{5}{|c|}{ Treatment (\% Crude glycerin) $)^{\mathrm{a}}$} & \multirow[t]{2}{*}{ SE } & \multicolumn{4}{|c|}{ Contrast, $P$-value ${ }^{\mathrm{b}}$} \\
\hline & 0 & 7.5 & 15 & 22.5 & 30 & & $\mathrm{~L}$ & $\mathrm{Q}$ & $\mathrm{C}$ & $0 \times$ Gly \\
\hline \multicolumn{11}{|l|}{ VFA, mM/L } \\
\hline Total VFA & 136.1 & 122.2 & 118.7 & 115.1 & 120.2 & 6.6 & 0.03 & 0.42 & 0.71 & 0.03 \\
\hline Acetic acid & 86.6 & 73.4 & 59.9 & 54.1 & 49.3 & 4.9 & $<0.0001$ & 0.39 & 0.68 & 0.0001 \\
\hline Propionic acid & 24.5 & 22.3 & 24.1 & 29.9 & 33.1 & 1.56 & 0.007 & 0.008 & 0.97 & 0.54 \\
\hline Isobutyric acid & 1.29 & 1.26 & 1.28 & 1.18 & 1.27 & 0.09 & 0.25 & 0.53 & 0.48 & 0.47 \\
\hline Butyric acid & 19.3 & 21.0 & 28.8 & 24.6 & 30.5 & 2.7 & 0.04 & 0.25 & 0.11 & 0.07 \\
\hline Isovaleric acid & 2.16 & 2.10 & 1.94 & 2.01 & 2.10 & 0.25 & 0.50 & 0.73 & 0.76 & 0.52 \\
\hline Valeric acid & 2.02 & 2.11 & 2.61 & 3.41 & 4.00 & 0.23 & 0.0001 & 0.13 & 0.91 & 0.01 \\
\hline Acetate:propionate & 3.65 & 6.56 & 2.82 & 1.92 & 1.53 & 0.16 & $<0.0001$ & 0.50 & 0.41 & $<0.0001$ \\
\hline $\mathrm{pH}$ & 6.39 & 6.11 & 6.20 & 6.27 & 6.23 & 0.11 & 0.48 & 0.04 & 0.32 & 0.05 \\
\hline $\mathrm{NH}_{3}-\mathrm{N}, \mathrm{mg} / \mathrm{dL}$ & 20.0 & 20.5 & 15.0 & 15.9 & 18.3 & 3.09 & 0.10 & 0.93 & 0.24 & 0.30 \\
\hline
\end{tabular}

a $\mathrm{GO}=$ Without crude glycerin; G7.5=75 g crude glycerin $/ \mathrm{kg}$ DM; G15=150 g crude glycerin $/ \mathrm{kg}$ DM; G22.5=225 g crude glycerin/kg DM; G30=300 g crude glycerin/kg DM.

${ }^{\mathrm{b}} \mathrm{L}=$ Linear; $\mathrm{Q}=$ Quadratic; $\mathrm{C}=$ Cubic; $0 \times$ Gly $=$ Treatment $\mathrm{G} 0 \times$ Glycerin treatments

\section{Results}

\subsection{Rumen $\mathrm{pH}$, ammonia, and VFA profiles}

Table 2 shows the effects of the inclusion of increasing concentrations of crude glycerin in the Nellore cattle diet on ruminal parameters. The total VFA concentration linearly decreased $(P=0.03)$ with the inclusion of increasing concentrations of crude glycerin. There was a linear reduction in the concentration of acetic acid $(P<0.0001)$, and a quadratic effect in the concentration of propionic acid $(P=0.008)$, leading to a linear decrease in the acetate:propionate ratio $(P<0.0001)$. Glycerin supplementation also increased butyric acid (linear, $P=0.04$ ) and valeric acid (linear, $P=0.0001$ ) concentration, however no changes were observed for isobutyric and isovaleric acids. Additionally, a treatment $\times$ sampling time interaction was observed for butyric acid $(P=0.03)$, with the greatest average values observed $4 \mathrm{~h}$ post-feeding $(32.08 \mathrm{mM} / \mathrm{L})$ and the least, $1 \mathrm{~h}$ before feeding $(17.16 \mathrm{mM} / \mathrm{L})$.
No changes were observed in ruminal $\mathrm{NH}_{3}-\mathrm{N}$ concentrations when crude glycerin was added up to $30 \%$ in Nellore cattle diets, however $\mathrm{pH}$ values were lesser in animals fed glycerin when compared with controls $(\mathrm{P}=0.05)$, and presented a quadratic effect with the least value being observed for treatment with $7.5 \%$ crude glycerin $(\mathrm{pH}=6.11, \mathrm{SE}=0.11)$. Time of sampling had an effect on $\mathrm{pH}(P<0.01)$. The values observed for the treatment without crude glycerin were close to 5.7 between 2 and 4 h post-feeding, tending $(P=0.06)$ to be lesser when compared the other treatments.

\subsection{Protozoal and bacterial fractions}

The inclusion of crude glycerin in the diet, regardless of the concentration, decreased the concentration of PAB $(P=0.003)$, and tended to promote a quadratic effect on this variable $(P=0.05$, Table 3). Although the concentration of OM of PAB did not change with the inclusion of crude glycerin, the concentration of PAB (mg

Table 3

Effects of crude glycerin on production and composition of protozoal and bacterial fractions of Nellore steers.

\begin{tabular}{|c|c|c|c|c|c|c|c|c|c|c|}
\hline \multirow[t]{2}{*}{ Item $^{\mathrm{a}}$} & \multicolumn{5}{|c|}{ Treatment (\% Crude glycerin) ${ }^{\mathrm{b}}$} & \multirow[t]{2}{*}{ SE } & \multicolumn{4}{|c|}{ Contrast, $P$-value ${ }^{\mathrm{c}}$} \\
\hline & 0 & 7.5 & 15 & 22.5 & 30 & & $\mathrm{~L}$ & Q & $\mathrm{C}$ & $0 \times$ Gly \\
\hline \multicolumn{11}{|l|}{ РАВ } \\
\hline $\mathrm{mg} \mathrm{DM} / \mathrm{kg}$ & 4046.5 & 3722.2 & 3809.8 & 3779.0 & 3471.2 & 128 & 0.03 & 0.05 & 0.11 & 0.003 \\
\hline$\% \mathrm{OM}$ & 72.2 & 71.9 & 71.5 & 72.1 & 71.5 & 0.86 & 0.86 & 0.51 & 0.71 & 0.68 \\
\hline mg OM/kg & 2919.9 & 2679.3 & 2723.6 & 2727.1 & 2483.5 & 84 & 0.02 & 0.02 & 0.15 & 0.001 \\
\hline mg N/kg DM & 239.8 & 225.7 & 235.7 & 233.8 & 215 & 26.3 & 0.72 & 0.26 & 0.13 & 0.19 \\
\hline$\% \mathrm{~N} / \mathrm{OM}$ & 9.25 & 9.53 & 9.82 & 9.69 & 9.76 & 0.27 & 0.03 & 0.19 & 0.51 & 0.02 \\
\hline \multicolumn{11}{|l|}{$\mathrm{LAB}$} \\
\hline $\mathrm{mg} \mathrm{DM} / \mathrm{L}$ & 2416.2 & 2268.3 & 2401.7 & 2165.1 & 1915.2 & 155 & 0.26 & 0.71 & 0.24 & 0.33 \\
\hline$\% \mathrm{OM}$ & 62.1 & 62.1 & 62.2 & 61.5 & 61.1 & 1.17 & 0.62 & 0.64 & 0.82 & 0.87 \\
\hline $\mathrm{mg} \mathrm{OM} / \mathrm{L}$ & 1502 & 1410.5 & 1501 & 1333 & 1170.2 & 90.8 & 0.25 & 0.63 & 0.22 & 0.34 \\
\hline mg N/L & 152.3 & 120.6 & 162.1 & 107.7 & 106.1 & 13.9 & 0.04 & 0.22 & 0.0006 & 0.06 \\
\hline$\% \mathrm{~N} / \mathrm{OM}$ & 9.70 & 8.40 & 10.39 & 7.90 & 8.97 & 0.72 & 0.22 & 0.34 & 0.01 & 0.26 \\
\hline \multicolumn{11}{|l|}{ LAP } \\
\hline $\mathrm{mg} \mathrm{DM} / \mathrm{L}$ & 2265.3 & 2083.4 & 2007.1 & 2051.5 & 1956.3 & 156 & 0.22 & 0.38 & 0.97 & 0.16 \\
\hline$\% \mathrm{OM}$ & 59.7 & 59.8 & 59.1 & 58.9 & 55.8 & 0.71 & 0.14 & 0.68 & 0.47 & 0.45 \\
\hline $\mathrm{mg} \mathrm{OM} / \mathrm{L}$ & 1252.5 & 1240.3 & 1185.1 & 1208.2 & 1084.3 & 94 & 0.17 & 0.39 & 0.95 & 0.13 \\
\hline $\mathrm{mg} \mathrm{N} / \mathrm{L}$ & 87 & 86.9 & 71.1 & 84.5 & 73.1 & 8.7 & 0.90 & 0.16 & 0.73 & 0.19 \\
\hline$\% \mathrm{~N} / \mathrm{OM}$ & 6.28 & 5.34 & 5.93 & 6.73 & 6.65 & 0.56 & 0.44 & 0.14 & 0.61 & 0.67 \\
\hline
\end{tabular}

${ }^{\mathrm{a}} \mathrm{PAB}=$ Particle-associated bacteria; $\mathrm{LAB}=$ Liquid-associated bacteria; LAP = Liquid-associated protozoa.

${ }^{\mathrm{b}} \mathrm{G} 0=$ Without crude glycerin; G7.5=75 g crude glycerin/kg DM; G15=150 g crude glycerin/kg DM; G22.5=225 g crude glycerin/kg DM; G30=300 g crude glycerin/kg DM.

${ }^{\mathrm{C}} \mathrm{L}=$ Linear; $\mathrm{Q}=$ Quadratic; $\mathrm{C}=$ Cubic; $0 \times$ Gly=Treatment $\mathrm{G} 0 \times$ Glycerin treatments. 
$\mathrm{OM} / \mathrm{kg}$ ), was lesser in treatments with this co-product, when compared with control treatment $(P=0.001)$, and showed a quadratic effect of treatments $(P=0.02)$. The concentration of nitrogen in $\mathrm{PAB}(\mathrm{mg} \mathrm{N} / \mathrm{kg})$, did not change among treatments, however the concentration of $\mathrm{N}(\% \mathrm{~N} / \mathrm{OM})$ increased $(P=0.02)$ with glycerin supplementation, and showed a linear effect with the treatments $(P=0.03)$.

There was interaction of glycerin treatments versus sampling time for the concentration of $\mathrm{PAB}$ ( $\mathrm{mg} \mathrm{DM} / \mathrm{kg}, P=0.02$ and $\mathrm{mg} \mathrm{OM} /$ $\mathrm{kg}, P=0.01$ ). At $4 \mathrm{~h}$ post-feeding with the glycerin treatments, we observed the least concentration of PAB.

The results presented in Table 3 show that the glycerin treatments did not affect the concentration of LAB (mg DM/L and mg $\mathrm{OM} / \mathrm{L}$ ). We also observed cubic effects of glycerin treatments on $\mathrm{N}$ concentration of $\mathrm{LAB}(\mathrm{P}=0.0006)$, and in the percentage of $\mathrm{N}$ of this bacterial fraction $(P=0.01)$. Comparing glycerin treatments with controls, a tendency of decreasing concentration of $\mathrm{N}(\mathrm{mg} \mathrm{N} /$ $\mathrm{L})$ in $\mathrm{LAB}$ was observed $(P=0.06)$. The average values observed for LAP were $2072.7 \mathrm{mg} \mathrm{DM} / \mathrm{L}, 58.7 \%$ OM, $1194.1 \mathrm{mg} \mathrm{OM} / \mathrm{L}, 80.5 \mathrm{mg} \mathrm{N} /$ $\mathrm{L}$, and $6.2 \% \mathrm{~N} / \mathrm{OM}$ (Table 3 ). There was interaction between treatment and post-feeding time $(P=0.02)$. Treatments with $15 \%$ crude glycerin and control diets increased the percentage of OM of LAP at $2 \mathrm{~h}$ post-feeding, when compared with the other treatments. Furthermore, the inclusion of $30 \%$ crude glycerin exhibited the least values at 4 and $12 \mathrm{~h}$ post-feeding.

\subsection{Greenhouse gases measurements}

The greater the concentration of crude glycerin added to the diets, the lesser was the production of methane in vitro after $12 \mathrm{~h}$ of incubation $(P<0.0001)$. Indeed, regardless of the concentration of glycerin added, methane production was always lesser than in the controls $(P=0.0001)$. The inclusion of crude glycerin also affected in vitro production of ruminal $\mathrm{CO}_{2}(P=0.02)$, with a cubic effect observed for the treatments $(P<0.0001)$, in which the least values were observed for those containing 7.5 and $30 \%$ of crude glycerin (Table 4).

\section{Discussion}

This study appears to be the first study using such elevated concentrations of glycerin. This is also important in the field of human nutrition, once it could mitigate the competition for feed ingredients between humans and animals. We report that the inclusion of $30 \%$ crude glycerin in beef cattle diet led to the withdrawal of $86 \%$ of corn from the animal rations and reduced emission of enteric methane. However, further studies are necessary to elucidate the effects on digestibility of dietary fiber and starch, identification of microorganism species associated with animal performance results.

\subsection{Ruminal parameters}

Increasing addition of crude glycerin to Nellore diets led to an unexpected linear decrease in total VFA because the pronounced reduction in acetic acid (as much as $43.1 \%$ ) was not matched by the increase in propionic acid (as much as 35.1\%). Indeed in the literature (Boyd et al., 2013; Chanjula et al., 2014), total VFA is not affected by glycerin diets, even when the proportions of acetic and propionic acid vary. For instance, when Ramos and Kerley (2012) and Chanjula et al. (2014) replaced dietary corn with up to $20 \%$ glycerin, they observed no changes in total VFA although the production of acetate linearly decreased and propionic acid increased. Previous studies such as the one published by Boyd et al. (2013) have shown that even adding small concentrations of glycerin to the diets (up to 4\%), it is possible to detect the same effect (acetic acid reduction and propionic acid increase), albeit with less intensity. The observed reduction in acetic acid may be explained by the deleterious selection of fibrolytic microorganisms, which are known to be sensitive to glycerin (Abo El Nor et al., 2010).

The inclusion of crude glycerin leads to a reduction in the amount of non-fiber carbohydrate in the diet. However, crude glycerin has similar fermentative characteristics, generating mostly propionic, and less butyric and valeric acids. Once ingested and in the animal rumen, glycerol mostly disappears in the first $24 \mathrm{~h}$ (Trabue et al., 2007).

Previous studies have reported the deleterious effect of glycerin on fiber digestibility (Donkin et al., 2009; Shin et al., 2012). Glycerin inclusion reduces the number of microorganisms involved in fiber digestion (Roger et al., 1992; Abo El-Nor et al., 2010); leading to the reduction of acetic acid, which is a by-product of fiber digestibility, and consequently reduces methane production, as we observed herein.

The linear increase observed in the production of butyric and valeric acids was also reported by Remond et al. (1993), Wang et al. (2009), and Shin et al. (2012). Glycerin is largely metabolized by specific groups of bacteria such as Megasphaera elsdenii and Selenomonas ruminantium (Stewart et al., 1997; Krehbiel, 2008). Megasphaera elsdenii produces butyric acid as one of its end products from the fermentation of lactic acid (Klieve et al., 2003), which is increased with inclusion of glycerin. On the other hand, Selenomonas ruminantium ferments glycerin and converts the succinate produced in the rumen by other bacteria to propionic acid (Wolin et al., 1997). Thus, the addition of crude glycerin in cattle diets may increase Megasphaera elsdenii and Selenomonas ruminantium populations resulting in changes in VFA profiles, increasing concentration of propionate and butyrate, as showed herein. The increased concentration of butyric acid plays an important role in rumen health, since it provides the rumen epithelium most of its energy requirements (Schröder and Südekum, 1999).

Decreases in ruminal $\mathrm{pH}$ may be deleterious to the fermentative activity of ruminal microorganisms (Strobel, Russell 1986). Several studies reported that the addition of crude glycerin reduces the ruminal pH (Kijora et al., 1998; Mach et al., 2009; Ramos

Table 4

Effects of crude glycerin on in vitro enteric greenhouse gas concentrations in Nellore steers

\begin{tabular}{|c|c|c|c|c|c|c|c|c|c|c|}
\hline \multirow[t]{2}{*}{ Item (mL/g DM) } & \multicolumn{5}{|c|}{ Treatment (\% Crude glycerin) $)^{a}$} & \multirow[t]{2}{*}{ SE } & \multicolumn{4}{|c|}{ Contrast, $P$-value ${ }^{\mathrm{b}}$} \\
\hline & 0 & 7.5 & 15 & 22.5 & 30 & & $\mathrm{~L}$ & Q & $\mathrm{C}$ & $0 \times$ Gly \\
\hline $\mathrm{CH}_{4}$ & 12.03 & 10.97 & 7.64 & 6.99 & 6.43 & 0.39 & $<0.0001$ & 0.12 & 0.18 & $<0.0001$ \\
\hline $\mathrm{CO}_{2}$ & 55.82 & 54.11 & 55.34 & 57.80 & 50.56 & 0.47 & 0.0006 & 0.0001 & $<0.0001$ & 0.02 \\
\hline
\end{tabular}

${ }^{a}$ G0 =Without crude glycerin; G7.5=75 g crude glycerin/kg DM; G15=150 g crude glycerin/kg DM; G22.5=225 g crude glycerin/kg DM; G30=300 g crude glycerin/kg DM.

${ }^{\mathrm{b}} \mathrm{L}=$ Linear; $\mathrm{Q}=$ Quadratic; $\mathrm{C}=$ Cubic; $0 \times$ Gly $=$ Treatment $\mathrm{G} 0 \times$ Glycerin treatments 
and Kerley, 2012), just as we observed herein for intermediate concentrations of glycerin. However, all values obtained in this study remained within the range considered as optimal for the fermentative activity of bacteria, between 6.0 and 6.4 (Van Soest, 1994).

The protein source used in present study derived from sunflower meal, which is greatly soluble in the rumen (over 93\%, Van Cleef, 2012). This may be the reason underlying the similar values of ruminal ammonia nitrogen observed among treatments. The average values obtained for this variable ranged from 15 to $20.5 \mathrm{mg} \mathrm{NH}-\mathrm{N} / \mathrm{dL}$, considered adequate for ruminal fermentative activities. Leng (1990) reported that ruminal ammonia nitrogen value must be greater than $10 \mathrm{mg} \mathrm{NH}-\mathrm{N} / \mathrm{dL}$ to maximize ruminal digestion of DM and greater than $20 \mathrm{mg} \mathrm{NH}_{3}-\mathrm{N} / \mathrm{dL}$ to increase ruminant DM intake.

\subsection{Protozoal and bacterial fractions}

The reduction in the concentration of PAB caused by the inclusion of crude glycerin in the diets is consistent with other reports that revealed reduction of the bacteria groups Butyrivibrio fibrisolvens and Ruminococcus flavefaciens (Abo El-Nor et al., 2010; Roger et al., 1992). These groups of bacteria are responsible for the digestion of the fibrous portion of feedstuff and are some of the microorganisms composing the PAB fraction (Michalet-Doreau et al., 2001). Because glycerin is liquid, its inclusion removes particulate ingredients from the diet, thereby reducing PAB.

The reason underlying the decrease in the concentration of nitrogen of LAB, which occurred without a decrease in the concentration of this fraction, is not clear. A possibility is that the inclusion of crude glycerin in the diets changes the osmolarity of the rumen fluid thus affecting the permeability of the bacterial membrane and changing the bacterial nutrient concentration. Although Mach et al. (2009) reported no effect on ruminal fluid osmolarity when they included up to $12 \%$ crude glycerin in diets, the explanation just given may still stand because in the present study the concentrations of glycerin added were greater.

Crude glycerin addition to diets did not affect the concentration of protozoa. This result contrasts to that reported by Fávaro et al. (2014), who showed a decrease in the LAP with inclusion of up to $20 \%$ crude glycerin in cattle diets. Here we found that LAB were also not affected, suggesting that both microorganism fractions associated with the liquid phase of rumen content was not affected by crude glycerin inclusion.

Taken together, our data suggest that the deleterious effect observed in PAB (Table 3), which is associated to the solid phase of the rumen content, is mostly related to the adherence of bacteria to feed particles.

\subsection{Greenhouse gases}

Recent studies have shown contrasting results of gas production, specifically methane, probably due to different methodologies adopted. Meale et al. (2013) and Avila-Stagno et al. (2013) found no effect of addition of glycerin on those parameters using maximal concentrations of 12 and $21 \%$ of this by-product, respectively. However, the decrease observed in methane concentration with the addition of glycerin, as also demonstrated in prior studies (Lee et al., 2011), could be a result of the decreased rumen fermentation of diets, evidenced by total VFA decrease, reduced acetate:propionate ratio generated by the fermentation of these diets, as well as the effect of decreasing concentration of NDF in treatments with greater concentrations of crude glycerin. Thus, the amount of $\mathrm{H}_{2}$ in the rumen decreases, and hence its availability for methanogen microorganisms, which use it to reduce $\mathrm{CO}_{2}$ to $\mathrm{CH}_{4}$ (Van Soest, 1994; Janssen, 2010). The decrease in the production of $\mathrm{CO}_{2}$ was lesser than that observed for $\mathrm{CH}_{4}$ (as much as 46.6 and $9.4 \%$, respectively). The disproportionate reduction of these gases may indicate a reduction in the population of methanogens, considering that much of the rumen methane comes from $\mathrm{CO}_{2}$ (McAllister and Newbold, 2008) and that methane production decreased dramatically, even with substrate $\mathrm{CO}_{2}$ available in the environment. Besides being indicators of energy loss by the animals (estimated between 6 and 18\% of the diet gross energy), these gases are important factors in global warming (Pedreira and Primavesi, 2006). Thus, the inclusion of crude glycerin in the diet of ruminants becomes an interesting alternative for mitigating methane emission by livestock.

\section{Conclusions}

The inclusion of up to $30 \%$ of crude glycerin in diets for beef cattle decreased ruminal concentration of total VFA and acetate, increased propionate, reduced production of particle-associated bacteria, and decreased production of methane.

Further studies using greater concentrations of crude glycerin in the diets of beef cattle are needed to evaluate the optimal concentration able to maintain productive and economic efficiency of beef production.

\section{Acknowledgment}

Authors think Fundação de Apoio à Pesquisa do Estado de São Paulo (FAPESP) for the financial support and Caramuru Alimentos S.A. for providing part of the ingredients used in this research.

\section{References}

Abo El-Nor, S., AbuGhazaleh, A.A., Potu, R.B., Hastings, D., Khattab, M.S.A., 2010. Effects of differing levels of glycerol on rumen fermentation and bacteria. Anim. Feed Sci. Technol. 162, 99-105.

Anderson, D., Anderson, J.D., Sawyer, J., 2008. Impact of the ethanol boom on livestock and dairy industries: What are they going to eat? J. Agric. Appl. Econ. 40, 573-579.

AOAC, 1990. Official Methods of Analysis, 15th ed. Association of Official Analytical Chemists, Inc. Virginia.

Avila-Stagno, J., Chaves, A.V., He, M.L., Harstad, O.M., Beauchemin, K.A., McGinn, S. M., McAllister, T.A., 2013. Effects of increasing concentrations of glycerol in concentrate diets on nutrient digestibility, methane emissions, growth, fatty acid profiles, and carcass traits of lambs. J. Anim. Sci. 91, 829-837.

Boyd, J., Bernard, J.K., West, J.W., 2013. Effects of feeding different amounts of supplemental glycerol on ruminal environment and digestibility of lactating dairy cows. J. Dairy Sci. 96, 470-476.

Chanjula, P., Pakdeechanuan, P., Wattanasit, S., 2014. Effects of dietary crude glycerin supplementation on nutrient digestibility, ruminal fermentation, blood metabolites, and nitrogen balance of goats. Asian Australas. J. Anim. Sci. 27, 365-374.

Donkin, S.S., Koser, S.L., White, H.M., Doane, P.H., Cecava, M.J., 2009. Feeding value of glycerol as a replacement for corn grain in rations fed to lactating dairy cows. J. Dairy Sci. 92, 5111-5119.

Fávaro, V.R., Ezequiel, J.M.B., D’Aurea, A.P., Sancanari, J.B.D., Junior, Homem, Van Cleef, A.C., E.H.C.B., Santos, V.C., 2014. A utilização de glicerina em dietas para bovinos altera a microbiota ruminal. Arch. Bras. Med. Vet. Zootec. 66, 1504-1512.

Gunn, P.J., Neary, M.K., Lemenager, R.P., Lake, S.L., 2010. Effects of crude glycerin on performance and carcass characteristics of finishing wether lambs. J. Anim. Sci. 88, 1771-1776.

Holter, J.B., Young, A.J., 1992. Nutrition, feeding and calves: methane prediction in dryand lactating Holstein cows. J. Dairy Sci. 75, 2165-2175.

Janssen, P.H., 2010. Influence of hydrogen on rumen methane formation and fermentation balances through microbial growth kinetics and fermentation thermodynamics. Anim. Feed Sci. Technol. 160, 1-22.

Kijora, C., Bergner, H., Gotz, K.P., Bartelt, J., Szakacs, J., Sommer, A., 1998. Research note: Investigation on the metabolism of glycerol in the rumen of bulls. Arch. Tierernahr. 51, 341-348.

Klieve, A.V., Hennessy, D., Ouwerkerk, D., Forster, R.J., Mackie, R.I., Attwood, G.T. 2003. Establishing populations of Megasphaera elsdenii YE 34 and Butyrivibrio fibrisolvens YE 44 in the rumen of cattle fed high grain diets. J. Appl. Microbiol. 
95, 621-630.

Krehbiel, C.R., 2008. Ruminal and physiological metabolism of glycerin. J. Anim. Sci. 86, 392, E-Suppl. 2.

Lee, S.Y., Lee, S.M., Cho, Y.B., Kam, D.K., Lee, S.C., Kim, C.H., Seo, S., 2011. Glycerol as a feed supplement for ruminants: In vitro fermentation characteristics and methane production. Anim. Feed Sci. Technol. 166-167, 269-274.

Leng, R.A., 1990. Factors affecting the utilization of "poor-quality" forages by ruminants particularly under tropical conditions. Nutr. Res. Rev. 3, 277-303.

Mach, N., Bach, A., Devant, M., 2009. Effects of crude glycerin supplementation on performance and meat quality of Holstein bulls fed high-concentrate diets. J. Anim. Sci. 87, 632-638.

Martin, C., Williams, A.G., Michalet-Doreau, B., 1994. Isolation and characteristics of the protozoa and bacterial fractions from bovine and ruminal contents. J. Anim. Sci. 72, 2962-2968.

Meale, S.J., Chaves, A.V., Ding, S., Bush, R.D., McAllister, T.A., 2013. Effects of crude glycerin supplementation on wool production, feeding behavior, and body condition of Merino ewes. J. Anim. Sci. 91, 878-885.

McAllister, T.A., Newbold, C.J., 2008. Redirecting rumen fermentation to reduce methanogenesis. Aust. J. Exp. Agr. 48, 7-13.

Michalet-Doreau, B., Fernandez, I., Peyron, C., Millet, L., Fonty, G., 2001. Fibrolytic activities and cellulolytic bacterial community structure in the solid and liquid phases of rumen contents. Reprod. Nutr. Dev. 41, 187-194.

NRC-National Research Council, 1996. Nutrient Requirements of Beef Cattle, 7th ed. National Academy Press, Washington, D.C.

Pedreira, S.M., Primavesi, O., 2006. Impacto da Produção Animal Sobre o Ambiente. In: Berchielli, T.T., Pires, A.V., Oliveira, S.G. (Eds.), Nutrição de ruminantes. Funep, Jaboticabal, pp. 497-511.

Pereira, E.M.O., Ezequiel, J.M.B., Biagioli, B., 2006. Methane and carbon dioxide production in vitro in ruminal liquid from different types of bovines fed with total mixed ration. Arch. Latinoam. Prod. Anim. 14, 120-127.

Pritchard, R.H., 1993. Bunk management. Land O'Lakes Beef Seminar, Cedar Rapids, IA, Columbus, NE, and Storm Lake, IA, 1-4:4. Land O' Lakes Inc., St. Paul, MN.

Ramos, M.H., Kerley, M.S., 2012. Effect of dietary crude glycerol level on ruminal fermentation in continuous culture and growth performance of beef calves. J. Anim. Sci. 90, 892-899.

Remond, B., Souday, E., Jouany, J.P., 1993. In vitro and in vivo fermentation of glycerol by rumen microbes. Anim. Feed Sci. Technol. 41, 121-132.

Roger, V., Fonty, G., Andre, C., Gouet, P., 1992. Effects of glycerol on the growth, adhesion, and cellulolytic activity of rumen cellulolytic bacteria and anaerobic fungi. Curr. Microbiol. 25, 197-201.

Schröder, A., Südekum, K.H., 1999. Glycerol as a by-product of biodiesel production in diets for ruminants. In: Wratten, N., Salisbury, P.A. (Eds.), New Horizons for an Old Crop Proceedings 10th International Rapeseed Congress. The Regional Institute Ltd., Gosford, New South Wales, Australia, p. 241.

Shin, J.H., Wang, D., Kim, S.C., Adesogan, A.T., Staples, C.R., 2012. Effects of feeding crude glycerin on performance and ruminal kinetics of lactating Holstein cows fed corn silage or cottonseed hull-based, low-fiber diets. J. Dairy Sci. 95, 4006-4016.

Stewart, C.S., Flint, H.J., Bryant, M.P., 1997. The Rumen Bacteria. In: Hobson, P.N. Stewart, C.S. (Eds.), The Rumen Microbial Ecosystem. Blackie Academic \& Professional, London, pp. 10-72.

Strobel, H.J., Russell, J.B., 1986. Effect of pH and energy spilling on bacterial protein synthesis by carbohydrate-limited cultures of mixed rumen bacteria. J. Dairy Sci. 69, 2941-2947.

Trabue, S., Scoggin, K., Tjandrakusuma, S., Rasmussen, M.A., Reilly, P.J., 2007. Ruminal fermentation of propylene glycol and glycerol. J. Agric. Food Chem. 55, 7043-7051.

Van Cleef, E.H.C.B., 2012. Glicerina bruta em dietas para bovinos da raça Nelore confinados. PhD Thesis - Unesp, Jaboticabal, SP.

Van Cleef, E.H.C.B., Ezequiel, J.M.B., D’Aurea, A.P., Fávaro, V.R., Sancanari, J.B.D., 2014 Crude glycerin in diets for feedlot Nellore cattle. Rev. Bras. Zootec. 43, 86-91.

Van Soest, P.J., 1994. Nutritional Ecology of the Ruminant, second ed. Cornell University Press, Ithaca, New York.

Wang, C., Liu, Q., Huo, W.J., Yang, W.Z., Dong, K.H., Huang, Y.X., Guo, G., 2009. Effects of glycerol on rumen fermentation, urinary excretion of purine derivatives and feed digestibility in steers. Livest. Sci. 12, 15-20.

Wolin, M.J., Miller, T.L., Stewart, C.S., 1997. Microbe-microbeinteractions. In: Hobson, P.N., Stewart, C.S. (Eds.), The Rumen Microbial Ecosystem. Blackie Academic \& Professional, London, pp. 467-491. 